\title{
ROTATION CAPACITY OF BOLTED FLUSH END-PLATE STIFFENED BEAM-TO-COLUMN CONNECTION
}

\author{
Krzysztof OSTROWSKI ${ }^{1}$, Aleksander KOZŁOWSKI ${ }^{2}$ \\ ${ }^{1}$ MTA Engineering, Rzeszów, Poland \\ ${ }^{2}$ Rzeszow University of Technology, Rzeszów, Polad
}

\begin{abstract}
One of the flexibility parameters of semi-rigid joints is rotation capacity. Plastic rotation capacity is especially important in plastic design of framed structures. Current design codes, including Eurocode 3, do not posses procedures enabling designers to obtain value of rotation capacity. In the paper the calculation procedure of the rotation capacity for stiffened bolted flush end-plate beam-to-column connections has been proposed. Theory of experiment design was applied with the use of Hartley's PS/DS-P:Ha plan. The $_{3}$ analysis was performed with the use of finite element method (ANSYS), based on the numerical experiment plan. The determination of maximal rotation angle was carried out with the use of regression analysis. The main variables analyzed in parametric study were: pitch of the bolt "w" (120-180 mm), the distance between the bolt axis and the beam upper edge $c_{g 1}(50-90 \mathrm{~mm})$ and the thickness of the end-plate $t_{\mathrm{p}}(10-20 \mathrm{~mm})$. Power function was proposed to describe available rotation capacity of the joint. Influence of the particular components on the rotation capacity was also investigated. In the paper a general procedure for determination of rotation capacity was proposed.
\end{abstract}

Keywords: rotation capacity, FEM analysis, hierarchical validation, plan of numerical experiment

\footnotetext{
${ }^{1}$ Corresponding author: MTA Engineering Sp. z o.o., ul. Poniatowskiego 14, 35-026 Rzeszów, e-mail: krzysztof.ostrowski@mta-online.net

2 Corresponding author: Rzeszow University of Technology, al. Powstańców Warszawy 12, 35-959 Rzeszów, e-mail: kozłowski@prz.edu.pl
} 


\section{INTRODUCTION}

Traditional design of steel structures was based on the assumption that the connections are either ideally hinged or fully rigid. Nowadays, this concept was changed to a semi-rigid joint design philosophy. The most important data for the analysis and design of frames with semi-rigid joints are the M- $\phi$ curves (moment versus rotation), which represent the joint behaviour. Main joint parameters are: moment resistance, initial stiffness and rotation capacity (Fig. 1). Plastic rotation capacity of joints plays a very important role in the advanced analysis of steel frames, especially in the plastic analysis of framed structures with semi-rigid connections.

The best way to obtain joint characteristics is to conduct experimental tests. In the whole world, hundreds of laboratory tests have been conducted, whose results are collected in the databases [3], [25]. However, those lab tests results very often do not provide the required data. In the laboratory tests the researchers often concentrated on determining only the joint resistance or/and initial stiffness, but not always on the maximum deformability of joints. Because of measuring difficulties, the rotation angle was not always recorded to the end of the test. Furthermore, laboratory tests are very expensive and time-consuming, therefore, they are conducted mainly for scientific reasons.

For the description of joint characteristic few mathematical formulas were used in the following forms: linear, bilinear, multi-linear, polynomial [9], spline functions, power functions and exponential [26]. Instead of statistical models listed above, mechanical models were used which were the basis for developing component method in the Eurocode 3 [7]. There were also attempts to use artificial neural networks. An extensive description and a summary of proposed methods to forecast joint behaviour can be found in [4], [8], [14], [15]. Currently, numerical analyses used for the forecast of joint behaviour are generally conducted by means of finite element method [11], [17].

The design procedures given in Eurocode 3 (EN 1993-1-8) allow estimating the moment resistance $\mathrm{M}_{\mathrm{j}, \mathrm{Rd}}$ and initial stiffness $\mathrm{S}_{\mathrm{j}, \mathrm{ini}}$ of the bolted joints, but there is not enough information for the calculation of a connection rotation capacity $\Phi_{\mathrm{cd}}$. There are only qualitative descriptions of rotation capacity of selected connection types. The previous analysis of rotation capacity was carried out with the use of component method [2], [16], [24], probabilistic analysis [1], [23] and finite element method [17], [19] but without a practical suggestion how to apply them in the design process.

The paper presents the global procedure for obtaining a quantitative estimation of plastic rotation capacity of stiffened beam-to-column end-plate connection with the use of advanced FEM analysis. In the analyzed exemplary joint, column was made from the profile HEB300 and the beam from the profile HEA360. The main 
variable factors in the analysis are the following: horizontal distance between the

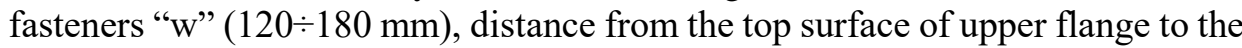
axis of bolts , $\mathrm{c}_{\mathrm{g} 1}$ " $(50 \div 90 \mathrm{~mm})$ and end-plate thickness " $\mathrm{t}_{\mathrm{p}}$ " $(10 \div 20 \mathrm{~mm})$.

Among many others, the following definition of joint rotation capacity is proposed: this is the rotation angle of joint, which can be achieved without the decrease of joint resistance. This is shown in a graphical representation in Fig. 1. According to this definition, it is possible to determine the maximum available rotation angle of a joint.

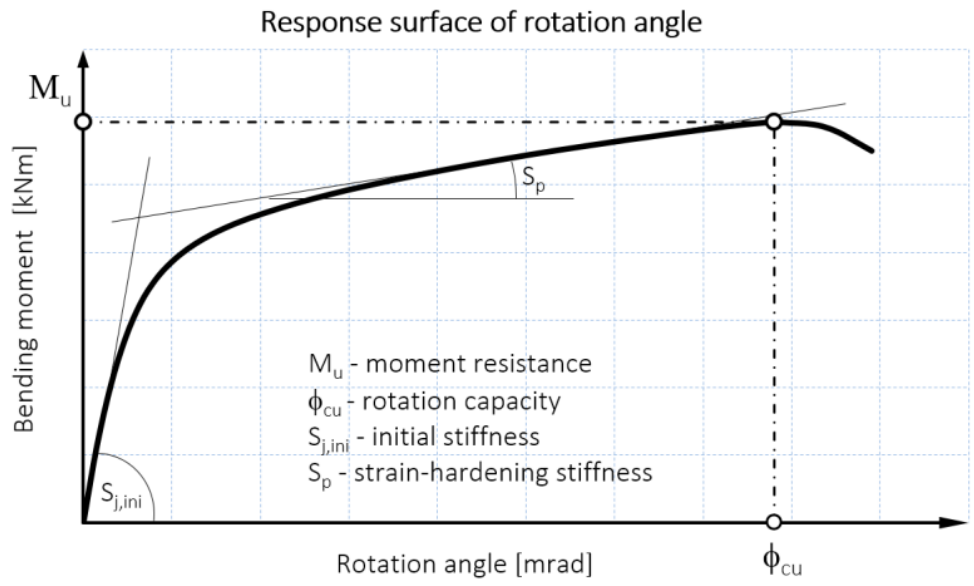

Fig. 1. Graphical representation of M- $\phi$ joint curve

\section{ALGORITHM OF ROTATION CAPACITY DETERMINATION}

Rotation capacity was assess by using following procedure:

- For selected type of connection the parametric study was carried out. In this analysis, three variable factors which have the greatest influence on the rotation capacity are identified. Scopes of variable factors, established in practically used ranges, were shown in Fig. 3.

- Constant factors are established such as: the grade of steel elements, the standard and class of bolts,

- The theory of experiment design is adopted to find approximation function for rotation capacity by the numerical simulation [21]. In the analyzed case, for the three variable factors, Hartley's plan PS/DS-P:Ha3 based on hypersphere with 11 combinations of variable factors was selected (see Table 1), 
- Fully validated by hierarchical validation procedures [18] FEM software was used to conduct numerical experiment for chosen geometrical parameters of joints,

- The results obtained in the numerical experiment were used for the determination of the available rotation angle function with the use of regression analysis.

The function of the maximal rotation angle was defined as a polynomial function as below:

$$
\phi_{c u}=t_{p}^{\alpha} \cdot c_{g 1}^{\beta} \cdot w^{\gamma}-A
$$

where: $\quad \alpha, \beta, \gamma$-are the coefficients of polynomial,

$t_{p}[\mathrm{~mm}]$ - is the thickness of end-plate,

$c_{g l}[\mathrm{~mm}]$ - is the distance from the top edge of upper flange to the axis of bolt, $w[\mathrm{~mm}]$ - is the spacing between the centres of bolts,

$A$ - is the constant of the polynomial.

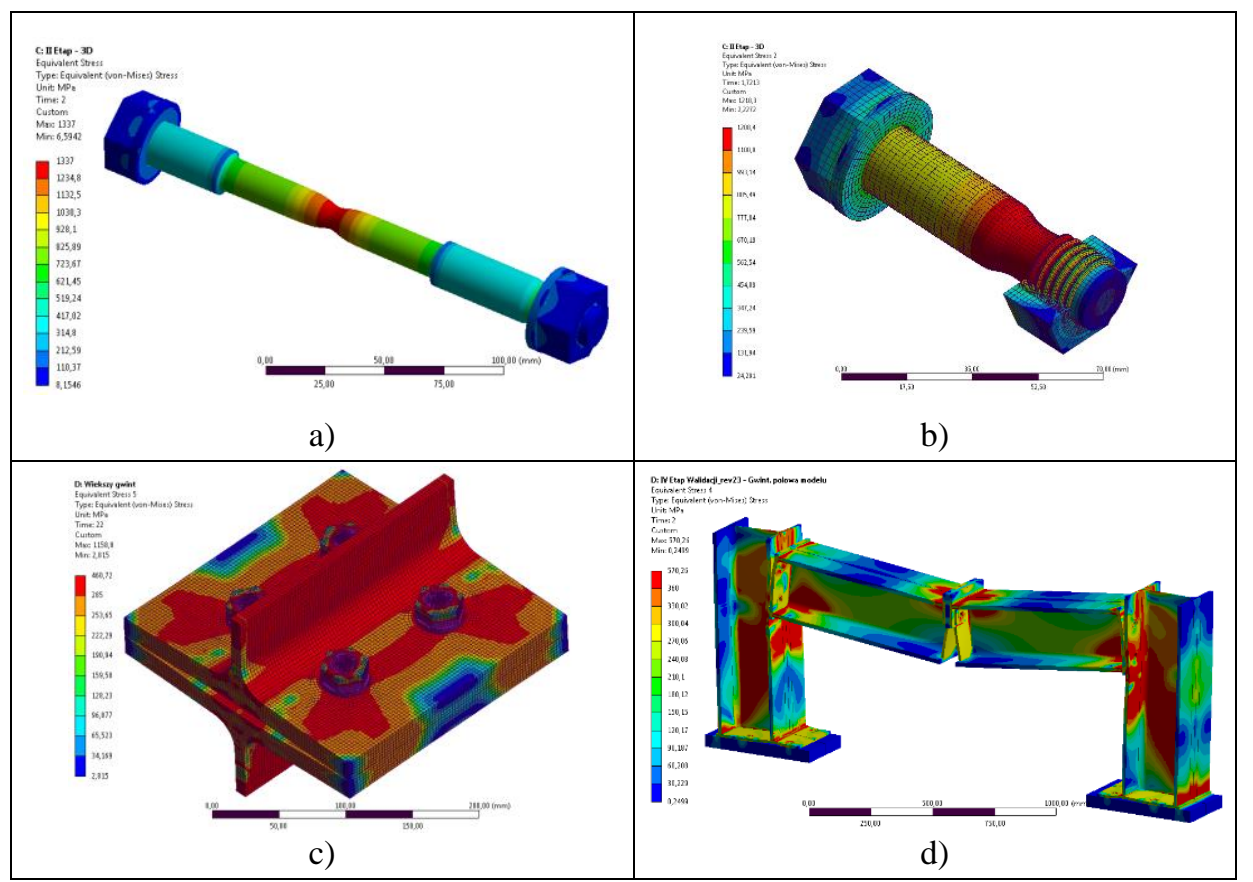

Fig. 2. Multistage Hierarchical Validation of FEM models: a) I stage - material sample; b) II stage - bolt-washer-nut set; c) III stage - T-stube; d) IV stage - the joint in the configuration of frame

The most important for accuracy of proposed procedure is proper results of FEM modelling. The results obtained in the Finite Elements Method may be considered 
as satisfying if the obtained results are comparable with the results of laboratory tests. In order to obtain similar results, the FEM model adjustment is necessary. Adjustment of models is reached by a hierarchical validation method [5], [6], [18], [22] in the comparative analysis of models with different level of complexity with the results of laboratory tests (Fig. 2).

Hierarchical validation has been conducted in the following steps [18]:

- the first and the basic is to carry out laboratory tests of materials used to make these joints [10], [18]. The tests are performed on specimen material of beams, columns and end - plates,

- $\quad$ then, the laboratory tests are performed on bolt - washer - nut sets [12], [13]. In this test, the strains of particular bolt elements were measured,

- in the next step experimental tests were conducted for T-stubs and for whole joint,

- the next step is to carry out a multi-stage, hierarchical validation of the FEM models. This validation consists in a comparison of laboratory tests' results with the results obtained in the FEM analysis. This process enables models' calibration. Material sample, bolt-washer-nut set, T-stub and complete joint model has been modelled and compared with laboratory own test results.

\section{NUMERICAL MODEL OF JOINT}

\subsection{Joint components}

The determination of the function describing the rotation angle of a bolted endplate beam-to-column connection was made on the basis of FEM analysis for an isolated joint, for which the response surface of rotation angle is defined on the basis of the plan of the numerical experiment. The function of the rotation angle was determined in relation to the above mentioned basic variables, whose location is shown in Fig. 3. The analysis was carried out with the use of Ansys software.

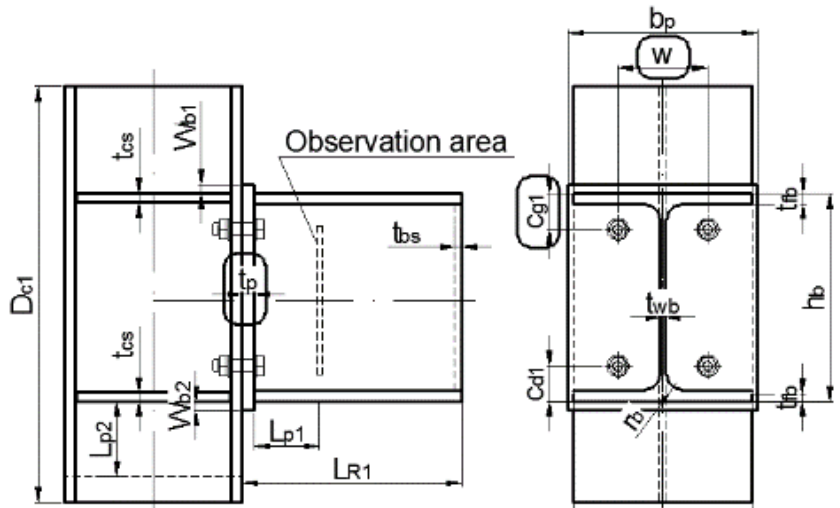

Fig. 3. Designation of variable factors: „tp”, „cg1” and „w” 


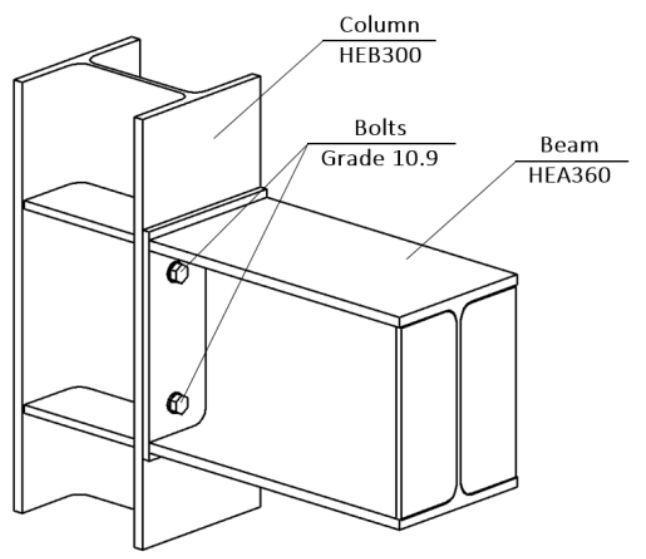

Fig. 4. FEM model - 3D view

For numerical model (Fig. 4) building the hexagonal, 8-node, cubic finite elements were used. The washers were modelled as separate elements. Bolt's shank was joined with the nut and bolt's head. In the model of washer, 3 layers of finite elements and the division into 48 elements were introduced (Fig. 5b). In the area where the thread connects to the nut, mesh density was increased to the size of $1 \mathrm{~mm}$ (Fig. 5a). In end - plate 6 layers of finite elements were introduced and adequately in the column in the area of contact with the plate. In order to increase the efficiency of calculations, the model of a half of the joint was made, with the use of symmetry with respect to a central plane of the system.

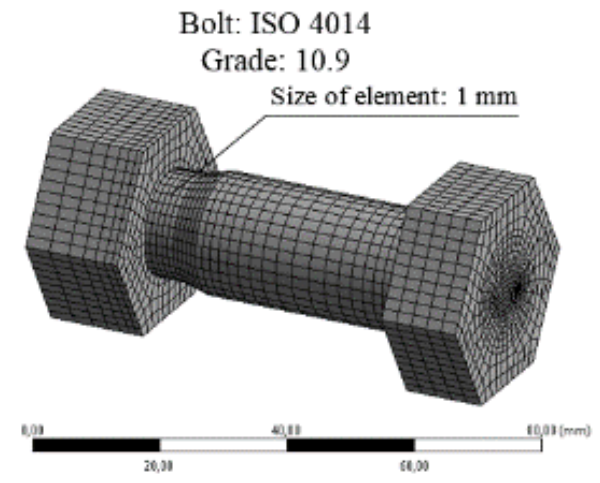

a)

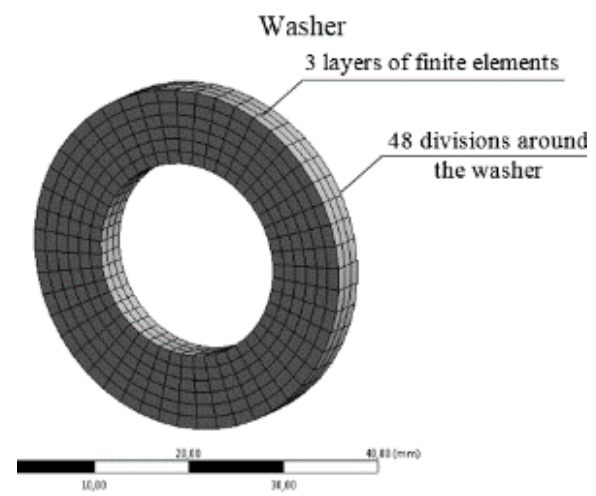

b)

Fig. 5. FEM model: a) bolt, b) washer

In every joint's component, mesh density of finite elements was introduced in reference to local stresses and strains. The mesh size of finite elements in the 
initial phase of analysis was created with the use of the adaptation method. For the creation of bolt's model 8-node, cubic elements were also used.

\subsection{Modelling of contact surface}

The contacts between particular joint elements were created as nonlinear with the friction factor assumed for the surface in a natural condition with the value of $\mu=0.2$. Contact surfaces were introduced in the areas of contact between: end plates, washer - end plate, washer-nut, washer-head of the bolt (Fig. 6c). Additionally, radial surfaces between bolt hole and bolt shank and thread were introduced in the model (Fig. 6b).

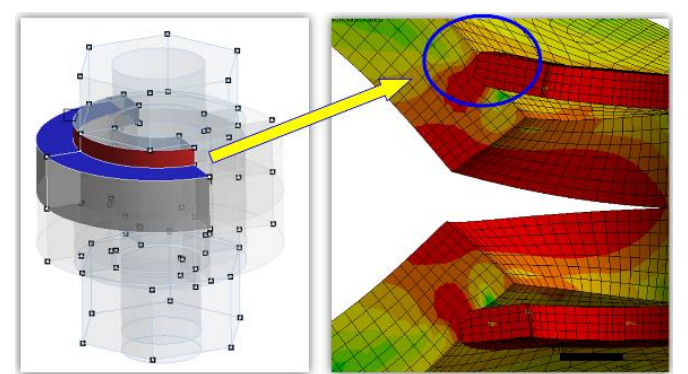

a)

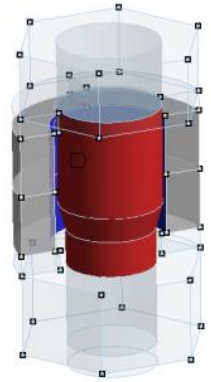

b)

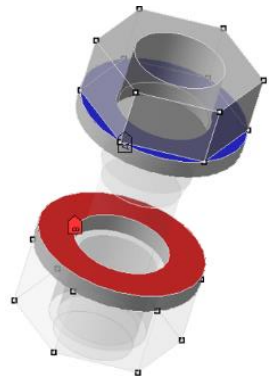

c)

Fig. 6. a) Contact between end plate and external surface of washer; b) Radial contact bolt-end plate-column; c) Antyslip contact washer - end plate

The last from mentioned contacts create boundary conditions to support the bolt that rests on the inner surface of the plate's hole caused by a large joint gap. A specific type of contact surface which has been introduced into the FEM model is shown in Fig. 6a. In the initial stage of joint deformation, the side surface of the washer and the upper surface of the plate have no contact, but with a large gap in the joint they interact between each other, and plate surface is the support for the washer. Introducing such contact surface is dictated by possible occurrence of non-coinciding the FEM model caused by penetrating objects.

\subsection{Methodology of load applying on the model}

In the research plan the FEM model was loaded by introducing of displacement at the end of the cantilever. The values of the displacement were experimentally set in such a way that we obtain the maximal angle, at which the tangent to a curve of response rotation angle has an inclination equal to 0 . The displacement was introduced in 50 steps. Bolts' pretensioning was defined as a separate, first step. Due to the prestressing of the fasteners, the thread flexibility was neglected. 
The bolt prestressing to the force $\mathrm{F}_{\mathrm{p}, \mathrm{C}}=175 \mathrm{kN}$ was executed by the application of the compression force to the lateral surface of the shank. In Fig. 7 the system of support and load location in the FEM model is shown.

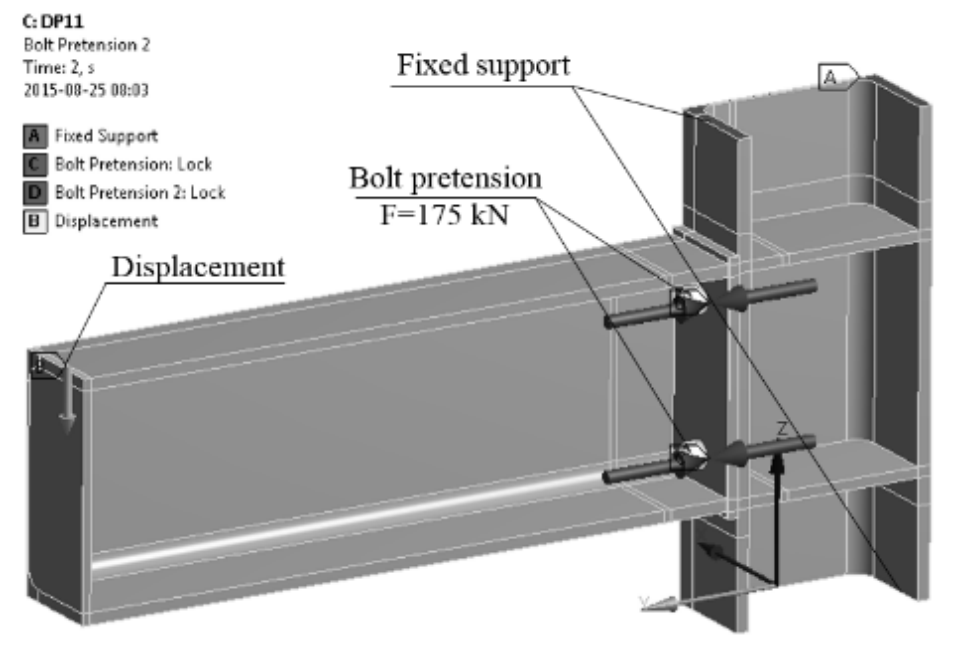

Fig. 7. FEM model - location of supports and loads

Table 1. Plan of Numerical Experiment (Hartley’s plan: PS/DS-P:Ha

\begin{tabular}{|c|c|c|c|c|c|c|c|}
\hline \multirow{3}{*}{$\mathrm{DP}_{\mathrm{i}}$} & & $\widehat{x}_{k}$ & & & $x_{k}$ & & \multirow{2}{*}{$\begin{array}{l}\text { Rotation } \\
\text { angle } \phi_{\mathrm{cu}}\end{array}$} \\
\hline & $\widehat{x}_{1}$ & $\widehat{x}_{2}$ & $\widehat{x}_{3}$ & $\mathbf{t}_{\mathbf{p}}$ & $\mathbf{c}_{\mathrm{g} 1}$ & $\mathbf{w}$ & \\
\hline & & & & {$[\mathrm{mm}]$} & {$[\mathrm{mm}]$} & {$[\mathrm{mm}]$} & [mrad] \\
\hline $\mathrm{DP}_{1}$ & -1 & -1 & 1 & 12,11 & 58,45 & 167,32 & 83,07 \\
\hline $\mathrm{DP}_{2}$ & 1 & -1 & -1 & 17,89 & 58,45 & 132,68 & 13,98 \\
\hline $\mathrm{DP}_{3}$ & -1 & 1 & -1 & 12,11 & 81,55 & 132,68 & 106,69 \\
\hline $\mathrm{DP}_{4}$ & 1 & 1 & 1 & 17,89 & 81,55 & 167,32 & 43,75 \\
\hline $\mathrm{DP}_{5}$ & $-1,732$ & 0 & 0 & 10,00 & 70,00 & 150,00 & 106,84 \\
\hline $\mathrm{DP}_{6}$ & 1,732 & 0 & 0 & 20,00 & 70,00 & 150,00 & 15,85 \\
\hline $\mathrm{DP}_{7}$ & 0 & $-1,732$ & 0 & 15,00 & 50,00 & 150,00 & 29,38 \\
\hline $\mathrm{DP}_{8}$ & 0 & 1,732 & 0 & 15,00 & 90,00 & 150,00 & 86,58 \\
\hline $\mathrm{DP}_{9}$ & 0 & 0 & $-1,732$ & 15,00 & 70,00 & 120,00 & 45,37 \\
\hline $\mathrm{DP}_{10}$ & 0 & 0 & 1,732 & 15,00 & 70,00 & 180,00 & 72,59 \\
\hline $\mathrm{DP}_{11}$ & 0 & 0 & 0 & 15,00 & $\begin{array}{l}70,00 \\
\end{array}$ & 150,00 & 59.81 \\
\hline
\end{tabular}

\section{RESULTS ANALYSIS}

Results of the FEM analysis [20] of eleven geometrical join arrangements are shown in Fig. 8. 


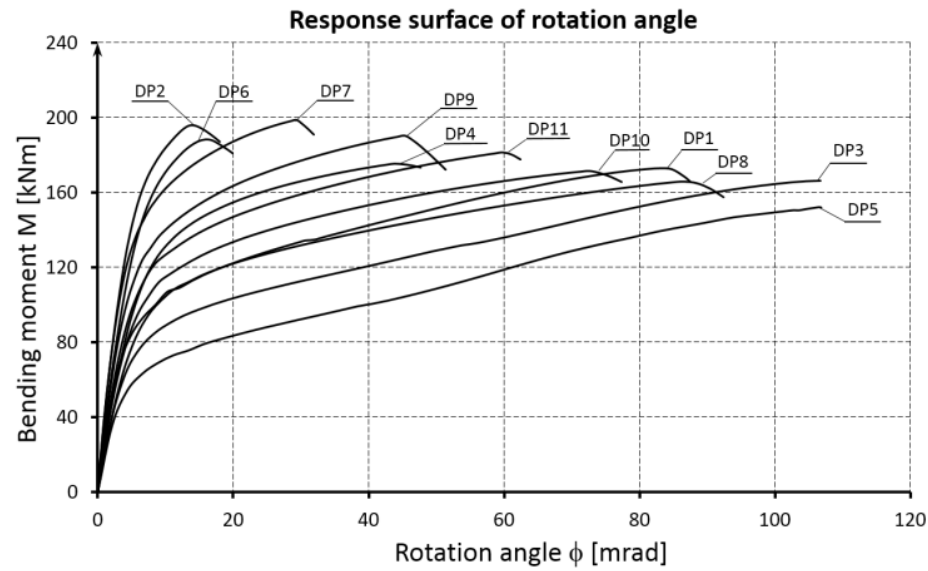

Fig. 8. Response surface of rotation angle of experiment plan

The coefficients of polynomial which are described by the equation (2.1) were calculated with the program Statistica 12, with the use of the nonlinear estimation method. Inserting the calculated coefficients $(\alpha, \beta, \gamma)$ into equation (4.1) one can receive the function of available rotation capacity of joint in the following form:

$$
\varphi_{c u}=t^{-1,267} \cdot c_{g 1}^{1,044} \cdot w^{0,714}-42,48
$$

The values of obtained rotation angles (Table 1) are in the range: $\phi_{\mathrm{cu}}=16,87 \div$ 121,02 [mrad]. In Fig. 9 the comparison of the rotation angles results obtained in the numerical experiments with rotation angles determined on the basis of the equation is presented.

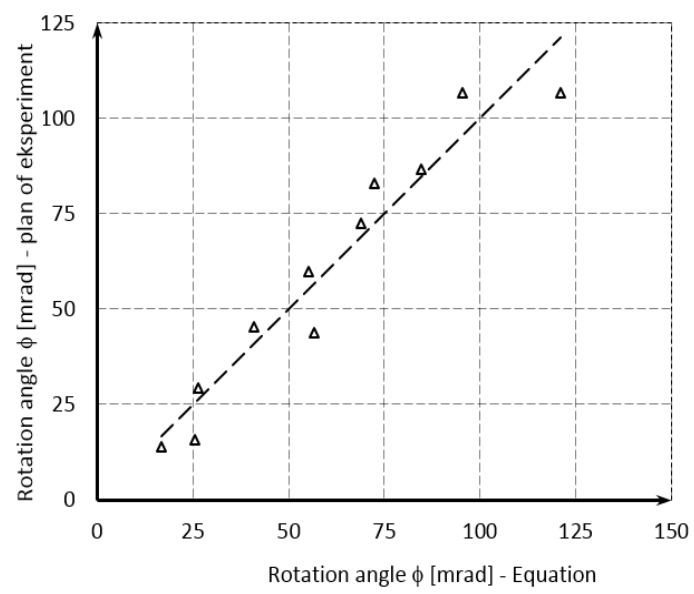

Fig. 9. Comparison of the rotation angles results obtained in experiment's plan with rotation angles determined on the basis of the equation (4.1) 


\section{SUMMARY}

The introduction of material characteristics into advance FEM analysis as a result of the multi - stages hierarchical validation is the essential condition for obtaining of reliable results of the FEM analysis.

The obtained results of the analysis clearly show the trend of achieving the maximal rotation angle $\phi_{\mathrm{cu}}$ resulted from the decreasing of bolt's load capacity, regardless of the failure modes acc. to EN 1993-1-8 existing in the connection. In connections in which the first failure mode occur the forces are regrouped which results in developing the "membrane" effect. The end - plate along with progressive rigidity degradation goes from a bending state into a membrane state, which does not have its analytical (quantitative) reference.

Proposed in the standard EN 1993-1-8 component method in the area of forecasting rotation capacity has been not fully developed which encourages discovering other, alternative, but possible and reliable methods of estimation of joint rotation capacity in steel structures. Presented procedures will be used in the creation of more general formulas including other beam and column section. Such formulas can be used in design practice.

Obtained results of values of rotation capacity allows designer to estimate safety of applied joints and whole structure.

\section{REFERENCES}

1. Beg D., Zupancic E.: Statistical evaluation of rotation capacity of moment connections, Connections in Steel Structures V, Amsterdam, 2004.

2. Beg D., Zupancic E., Vayas I.: On the rotation capacity of moment connections. Journal of Constructional Steel Research, 60: 601-620, 2004.

3. Chen W.F., Kishi N.: Semirigid Steel Beam-to-Column Connections: Data Base and Modelling, Journal of Structural Engineering, ASCE, Vol. 115, No $1,1989$.

4. Concepcion D., Pascual M., Mariano V., Osvaldo M.Q.: Review on the modelling of joint behavior in steel frames, Journal of Constructional Steel Research 67: 741-758, 2011.

5. EN 1993-1-4. Eurocode 3: Design of steel structures, Part 1.4: General rules, Supplementary Rules for Stainless steels. Brussels: CEN.

6. EN 1993-1-5. Eurocode 3: Design of steel structures, Part 1.5: Plated structural elements. Brussels: CEN.

7. EN 1993-1-8.: Eurocode 3: Design of steel structures - Part 1-8: Design of joints. Brussels: CEN, 2005.

8. Faella C., PilusoV., Rizzano G.: Structural steel semi rigid connections: Theory, design and software. CRC Press, Boca Raton, 2000. 
9. Frye M. J., Morris G. A.: Analysis of Flexibly-Connected Steel Frames. Canadian Journal of Civil Engineering, No2. 1975.

10. Girao A.M., Bijlaard F., Gresnigt N., Silva L.: Experimental assessment of the behavior of bolted T-stub connections made up of welded plates, Journal of Constructional Steel Research. 2004. 60: 269-311.

11. Girao A. M., Silva L., Bijlaard F.: Finite-Element Modeling of the Nonlinear Behavior of Bolted T-Stubs Connections, Journal of Structural Engineering. 2006, 132: 918-928.

12. ISO 6892-1.: Metallic materials - Tensile testing, Part 1: Method of test at room temperature, 2009.

13. ISO 898-1.: Mechanical properties of fasteners made of carbon steel and alloy steel, Part 1: Bolts, screws and studs with specified property classes - Coarse thread and fine pitch thread.

14. Jaspart J. P.: Comparison between Experimental Tests, Numerical Simulations and Available Theoretical Procedures in View of Analytical Prediction of the Semi-Rigid Behavior of Beam-to-Columns Joints with Extended End Plate or Welded Connections, Technical Report No 4, SPRINT CONTRACT 351, 1993.

15. Kozlowski A.: A Review of Models of Semi-Rigid Steel Column-Beam Connections, Archives of Civil Engineering, Vol. XLII, Issue 1, 1996.

16. Kuhlmann U., Fürch A.: Rotation Capacity of Steel Joints, COST Project C1 Meeting, 1997.

17. Ostrowski K.: Finite element analysis of the rotation capacity of beam-tocolumn end-plate bolted joints, Eurosteel 2014, September 10-12, Naples, 2014.

18. Ostrowski K., Kozlowski A.: Hierarchical validation of FEM models, XIV International Scientific Conference Rzeszów - Lwów - Koszyce, Rzeszów, 2015.

19. Ostrowski K., Kozlowski A.: Parametric study on the rotation capacity of stiffened end-plate beam-to-column connection, (In Polish) Building and Architecture, Vol. 13(3) 2014, Lublin, 2014.

20. Ostrowski K., Kozlowski A.: FEM based assessment of rotation capacity of bolted joints, Proceedings of the XIII International Conference on Metal Structures (ICMS2016), Zielona Góra, Poland, 15-17 June, 2016.

21. Polanski Z.: Experiment design in technique, (In Polish), PWN, Warsaw.

22. Rasmussen K.J.R., 2003.: Full-range stress-strain curves for stainless steel alloys, Journal of Constructional Steel Research, 1984. 59: 47-61.

23. Silva S., Borges L., Garvasio H.: A probabilistic evaluation of the rotation capacity of end-plate beam-to-column steel joints, Connections in Steel Structures V, Amsterdam, 2004. 
24. Silva S., Girao A.: A ductility model for steel connections, Journal of Constructional Steel Research, 2001, 57: 45-70.

25. Weynand K.: SERICON - Databank on Joints in Building Frames. COST PROJECT C1, Proc. of the First State of the Art Workshop, 1992.

26. Yee Y.L., Melchers R.E.: Moment Rotation Curves for Bolted Connections, Journal of Structural Division, ASCE. Vol. 112, ST3, 1986.

\title{
ZDOLNOŚĆ DO OBROTU UŻEBROWANEGO POŁĄCZENIA Z BLACHĄ WPUSZCZONĄ BELKI ZE SŁUPEM
}

\begin{abstract}
Streszczenie
Jednym z parametrów podatnosciowych węzłów podatnych jest zdolność węzła do obrotu. Zdolność do obrotu jest szczególnie ważna w przypadku projektowania plastycznego konstrukcji szkieletowych. Normy projektowe, w tym Eurokod 3, nie zawierają procedur pozwalających obliczyć wartość obrotu węzła. W artykule przedstawiono procedurę obliczeniową prowadzącą do oszacowania zdolności do obrotu węzła doczołowego $\mathrm{z}$ blachą wpuszczoną. Wartości do wyznaczenia funkcji kąta obrotu uzyskano na podstawie analizy wykonanej metodą elementów skończonych, w oparciu o pięciowartościowy plan eksperymentu numerycznego Hartleya PS/DS-P:Ha3. Funkcję kąta obrotu wyznaczono z uwzględnieniem podstawowych zmiennych wpływających na obrót węzła, jakimi są: grubość blachy czołowej „t, odległość śruby od górnej półki „, $\mathrm{c}_{\mathrm{g} 1}$ ”. Współczynniki funkcji maksymalnego kąta obrotu węzła wyznaczono metodą estymacji nieliniowej. Dokonano oceny wpływu oddziaływań poszczególnych elementów składowych węzła na graniczną wartość kąta obrotu węzła.
\end{abstract}

Słowa kluczowe: zdolność do obrotu, analiza MES, walidacja hierarchiczna, plan eksperymentu numerycznego

Editor received the manuscript: 10.07.2016 